\title{
Quality assessment of electronic state and municipal services using the example of the ministry of agriculture of the Russian Federation
}

\author{
Niyaz Azatovich Safiullin*, Gulnara Rinatovna Valieva, Dzhaudat Ibragimovich Faizrahmanov, Luisa Nizamovna \\ Savushkina, and Chulpan Malikovna Kurakova
}

Kazan State Agrarian University, 420015 Kazan, Russia

\begin{abstract}
The article discusses the features of the provision of public services in electronic form. The dynamics of the provision of public services in the Republic of Tatarstan is given. A review of the existing methodologies for assessing the quality of the provision of electronic public services is given. The authors' methodology for assessing the quality of the provision of state and municipal services in electronic form is proposed. An authorized executive body has been identified which is responsible for organizing the assessment of the quality of services. Formulas of individual indicators of the technique are developed. As an example, the assessment of the provision of the public service "Providing information obtained in the course of accounting for reclaimed land" is calculated. A polygon of the effectiveness of the provision of state and municipal services in electronic form is proposed. Measures to eliminate identified deficiencies in the provision of services are proposed. The authors make the conclusion about the importance of assessing the quality of services and the relevance of the proposed methodology.
\end{abstract}

\section{Introduction}

The effective use of modern technologies within egovernment system to a large extent depends on the utilized hardware and software complex, algorithms and information protection systems, as well as quality assessment of electronic public systems, including the system of electronic public services [1].

State and municipal services in the electronic form are services provided using information and telecommunication technologies, including the portal of state and municipal services, mobile application and appeals to a multifunctional center, as well as on official websites of the corresponding agencies, including electronic interaction between state bodies, local selfgovernment bodies, organizations and applicants.
The use of information technologies by state and municipal authorities has become one of the priority areas of information policy of both the Republic of Tatarstan and the Russian Federation as a whole. Their use can significantly improve the efficiency and quality of services provided to citizens, ensure openness of state authorities and enable public control over state authorities. However, in order to achieve the maximum results, there is a need for a comprehensive strategy of informatization of state and regional authorities, which includes synchronous implementation of several measures.

The Republic of Tatarstan is a recognized leader in the field of information support of various spheres of activity. In the field of electronic services, in 2016-2018 the Republic of Tatarstan took the first place in the Volga Federal District. [2]

Table 1. Information on state and municipal services in electronic form over 2014-2018

\begin{tabular}{|l|c|c|c|c|c|}
\hline \multirow{2}{*}{\multicolumn{1}{|c|}{ Services }} & \multicolumn{5}{|c|}{ Years } \\
\cline { 2 - 6 } & 2014 & 2015 & 2016 & 2017 & 2018 \\
\hline Aplications, mln pcs & 1.73 & 2.8 & 4.59 & 5.71 & 8.13 \\
\hline Queue entries, pcs & 3.42 & 8.3 & 15.78 & 18.49 & 18.80 \\
\hline Payments, pcs & 3.08 & 5.99 & 10.22 & 12.42 & 14.12 \\
\hline Total services, mln pcs & 32.70 & 60.33 & 88.54 & 127.83 & 211.30 \\
\hline Paid amount, bln rub. & 3.05 & 6.53 & 10.96 & 16.09 & 20.23 \\
\hline
\end{tabular}

In 2018 the number of services exceeded 211 million pieces, which is 6 times more than in 2014. The amount of payments made more than 20 billion rubles, which is 6 times higher than in 2014. Other indicators in the table

\footnotetext{
* Corresponding author: nsafiullin@ outlook.com
} 
show similar growth rates. This highlights an increase in the popularity of state and municipal services in electronic form among citizens of the Republic of Tatarstan. [3]

\section{Materials and methods}

The main indicator demonstrating the efficiency of executive authorities is the quality of public services. The importance of the quality analysis cannot be overestimated. The results can form the basis for policy directions to improve public administration. The results of the analysis will determine the effectiveness of decisions and actions. [4]

Studies in the field of methods of quality assessment of public services revealed major problems impeding the improvement of the efficiency of executive authorities: lack of legislative standards in this area, absence of general rules for quality assessment of public services, insufficient regulatory and legal support, etc.

Therefore, the authors propose a universal methodology for quality assessment of state and municipal services in the electronic form.

The proposed methodology of quality assessment of electronic public services is aimed at identifying typical and private problems of transferring state and municipal services into electronic form, their systematization and analysis, providing heads of departments transferring state and municipal services into electronic form with information necessary for making management decisions on the basis of quality assessment and analysis of transferring services into the electronic form. [5]

The quality assessment of electronic public services will be carried out by an authorized body in the field of electronic government, namely the Ministry of Digital Development, Communications and Mass Communication of the Russian Federation on the basis of this proposed methodology.

The quality assessment of electronic public services is based on the principles of legality, objectivity, impartiality, confidentiality, transparency, comprehensiveness and reliability.

The sources of information for quality assessment of electronic public services are as follows:

- official websites of public authorities;

- Public Services Portal of the Russian Federation;

- multifunctional center for state and municipal services;

- system of interdepartmental electronic interaction.

Table 2. Methods of quality assessment of electronic state and municipal services

\begin{tabular}{|c|c|c|c|c|}
\hline No. & Indicator & \multicolumn{2}{|c|}{$\begin{array}{c}\text { Specific } \\
\text { weight, points }\end{array}$} & Assessment method \\
\hline \multirow{3}{*}{1} & \multirow{3}{*}{$\begin{array}{l}\text { Approved administrative } \\
\text { regulations for electronic public } \\
\text { services provided by a public } \\
\text { authority }\end{array}$} & \multirow{3}{*}{3} & 3 & $\begin{array}{l}\text { There are approved administrative regulations of electronic } \\
\text { public service }\end{array}$ \\
\hline & & & 1 & $\begin{array}{l}\text { There is information on the procedure on electronic public } \\
\text { service, but there is no approved regulation }\end{array}$ \\
\hline & & & 0 & There are no administrative regulations \\
\hline \multirow{3}{*}{2} & \multirow{3}{*}{$\begin{array}{l}\text { Monitoring of electronic public } \\
\text { services to an applicant's request }\end{array}$} & \multirow{3}{*}{3} & 3 & $\begin{array}{l}\text { There is a possibility of monitoring via website, SMS, e-mail, } \\
\text { single phone number and/or hotline/call center }\end{array}$ \\
\hline & & & 1 & $\begin{array}{l}\text { There is a possibility of monitoring via SMS, email, single phone } \\
\text { number and/or hotline/call center }\end{array}$ \\
\hline & & & 0 & There is no possibility of monitoring \\
\hline \multirow{3}{*}{3} & \multirow{3}{*}{$\begin{array}{l}\text { Online surveys to improve } \\
\text { electronic public services }\end{array}$} & \multirow{3}{*}{3} & 3 & $\begin{array}{l}\text { There are online surveys, which are updated at least once a } \\
\text { month (at least } 5 \text { surveys) and their results are published }\end{array}$ \\
\hline & & & 1 & $\begin{array}{l}\text { There are online surveys, which are updated less than once a } \\
\text { quarter (at least } 5 \text { surveys), and their results are not published }\end{array}$ \\
\hline & & & 0 & There are no online surveys to improve electronic public services \\
\hline \multirow{3}{*}{4} & \multirow{3}{*}{$\begin{array}{l}\text { Assessment tool of electronic } \\
\text { public services }\end{array}$} & \multirow{3}{*}{3} & 3 & There is a functioning assessment tool \\
\hline & & & 1 & There is an assessment tool but it is not working \\
\hline & & & 0 & No tool available \\
\hline \multirow{3}{*}{5} & \multirow{3}{*}{$\begin{array}{l}\text { Degree of automation of electronic } \\
\text { public services }\end{array}$} & \multirow{3}{*}{3} & 3 & Through the Single Portal and official website \\
\hline & & & 1 & Only through the Single Portal \\
\hline & & & 0 & Official website \\
\hline \multirow{3}{*}{6} & \multirow{3}{*}{$\begin{array}{l}\text { Degree of maturity of electronic } \\
\text { public services }\end{array}$} & \multirow{3}{*}{3} & 3 & Transactional interactive public services \\
\hline & & & 1 & $\begin{array}{l}\text { Interactive public services in the form of bilateral information } \\
\text { exchange }\end{array}$ \\
\hline & & & 0 & $\begin{array}{l}\text { Electronic public services in the form of unilateral } \\
\text { interactions }\end{array}$ \\
\hline \multirow{3}{*}{7} & \multirow{3}{*}{$\begin{array}{l}\text { Compliance with deadlines for } \\
\text { electronic public services }\end{array}$} & \multirow{3}{*}{3} & 3 & There is no violation of deadlines \\
\hline & & & 1 & There is at least one violation of deadlines \\
\hline & & & 0 & There is more than one violation of deadlines \\
\hline \multirow{3}{*}{8} & \multirow{3}{*}{$\begin{array}{l}\text { Satisfaction with electronic public } \\
\text { services }\end{array}$} & \multirow{3}{*}{3} & 3 & Excellent and good \\
\hline & & & 1 & Satisfactory \\
\hline & & & 0 & Unsatisfactory \\
\hline & Total score & & & 24 \\
\hline
\end{tabular}


According to the proposed methodology, the quality assessment of electronic public services is carried out according to the following criteria:

- procedure on electronic public services;

- monitoring of electronic public services;

- online surveys to improve electronic public services;

- assessment tool of electronic public services;

- degree of automation of public services;

- compliance with deadlines for electronic public services;

- satisfaction of applicants in electronic public services.

For each criterion there are indicators, according to which the scores are determined (Table 2).

The first indicator is assessed for the presence of approved regulations of electronic public services provided by a state body according to the formula:

$$
R_{\text {app }}=\left(\sum_{i=1}^{n} Y\right) / n
$$

where:

$\mathrm{R}_{\text {app }}$ - coefficient of approved regulations on electronic public services; $\mathrm{n}$ - number of all electronic public services provided by a state body; i - sequence number of a service (from 1 to $n$ ); $\mathrm{Y}$ - specific weight of an indicator.

The next indicator is assessed to determine whether there is a mechanism to monitor the progress of $\mathrm{e}$ electronic public services provided through the website of the public authority using the following formula:

$$
Z_{\text {prog }}=\left(\sum_{i=1}^{n} Y\right) / n
$$

where:

$\mathrm{Z}_{\text {prog }}$ - coefficient of availability of a mechanism to monitor the progress of electronic public services provided at the request of an applicant within the scope of electronic public services approved by the regulations; $n$ - number of all electronic public services provided by a public authority; $\mathrm{i}$ - service sequence number (from 1 to $\mathrm{n}) ; \mathrm{Y}$ - specific weight of an indicator.

The third indicator is assessed for the availability of online surveys to improve electronic public services implemented on the website of a public authority.

The assessment is carried out to check the availability of a tool to monitor the progress of electronic public services provided through the website of a public authority, according to the following formula:

$$
Z_{\text {res }}=\left(\sum_{i=1}^{n} Y\right) / n
$$

where:

$\mathrm{Z}_{\text {res }}$ - coefficient of availability of a tool for an applicant to assess the result of obtaining electronic public services; $\mathrm{n}$ - number of all electronic public services provided by a public authority; $\mathrm{i}$ - service sequence number (from 1 to $\mathrm{n}$ ); $\mathrm{Y}$ - specific weight of an indicator.

The assessment is carried out on the basis of analysis of approved regulations on electronic public services specified in the Unified Register. The assessment is performed according to the following formula:

$$
K_{\text {auto }}=\frac{\sum_{u=1}^{n} * Y}{n}
$$

Here:

$$
\mathrm{u}=\mathrm{b} * \frac{x}{y}, \text { if: } \mathrm{y}=\text { " } 0 \text { ", then } \mathrm{u}=\mathrm{b}
$$

where:

$\mathrm{K}_{\text {auto }}$ - coefficient of automation of electronic public services; $\mathrm{u}$ - assigned final score of a certain electronic public service; $\mathrm{n}$ - number of all electronic public services provided by a public authority; i - service sequence number (from 1 to $\mathrm{n}$ ); $\mathrm{y}$ - specific weight of an indicator.

$\mathrm{x}$ - number of operational and functional processes related to electronic public service, which are automated and implemented through information systems; $y$ - total number of operational and functional processes associated with an electronic public service; $b$ - coefficient of a public service, in case the electronic public service is provided: through the Single Portal and the official website $-\mathbf{1}$; only through the Single Portal $-\mathbf{0 . 5}$; only through the official website $\mathbf{- 0 . 5}$.

According to the legislation, electronic public services can be rendered as information and interactive public services. An information public service is an electronic public service aimed at meeting the information needs of applicants and provided through publication and other dissemination of information on the activities of a state body. An interactive public service is an electronic public service provided to an applicant through bilateral electronic interaction between the applicant and the public authority rendering electronic public services. [6]

The maturity of electronic public services can be described as follows:

- information public services are provided by publishing (distributing) publicly available information implementation of services to ensure access to state information resources through appropriate information systems, including the Internet;

interactive public services of unilateral interaction are rendered by providing access to various forms of documents in the electronic form;

- interactive public services of bilateral information exchange are carried out through services rendered by state bodies, including reception, analysis (consideration) and response to a request (submission of requests, submission and/or retrieval of results of their processing);

- transactional interactive public services are provided by means of full data exchange in the electronic form, including through provision and payment of a service.

The assessment is carried out on the basis of the received statistics from the Unified Portal on compliance with deadlines for electronic public services. Statistical data on interdepartmental electronic requests are also taken into account through the system of interdepartmental electronic cooperation, which ensures cooperation between state bodies in order to implement their functions and tasks related to electronic public services [7]. 
The assessment is carried out for compliance with the deadlines for electronic public services in accordance with approved regulations of electronic public services.

The assessment is carried out on the basis of assessments by applicants for electronic public services. All electronic public services provided through the Unified Portal shall be assessed on a scale from one to five according to the formula:

$$
\begin{aligned}
& \mathrm{K}_{\text {sat }}=\left(\frac{\sum_{i=1}^{n} z}{n}\right. \\
& \text { where: }
\end{aligned}
$$

$\mathrm{K}_{\text {sat }}$ - satisfaction rate in obtaining electronic public services; $\mathrm{j}$ - number of request for electronic public services; $\mathrm{n}$-number of electronic public services assessed by applicants; $\mathrm{Z}$ - assessment of applicants for received electronic public service I (from 1 to 5).

$$
\left.\mathrm{K}_{\text {final }}=\left(\frac{\frac{\sum_{i=1}^{n} Z}{m}}{5}\right) * Y\right)
$$

where:

$K_{\text {final }}$ - final coefficient of "Satisfaction in receiving electronic public services"; $m$ - number of electronic public services assessed by applicants; Y - specific weight of an indicator.

The final stage of the introduced assessment is annual submission of the quality assessment results on electronic public services to the Government of the Republic of Tatarstan.

The quality assessment results of electronic public services shall be regularly published in media.

Public authorities providing electronic public services are obliged to take measures to improve the quality of their provision, taking into account the assessment results. [8]

The Ministry of Agriculture of the Russian Federation implements the following services in the electronic form on the Portal of Public Services:
1. Maintenance of a state register of self-regulatory organizations of inspection union of agricultural cooperatives.

2. Issue of decision attached to an application for state registration of the designation of origin of goods and exclusivity to such name.

3. State registration of breeding herds and maintenance of the state breeding register.

4. Identification of types of organizations active in the field of livestock husbandry.

5. Certification of state reclamation systems and separately located hydraulic structures classified as state property.

6. Provision of information obtained through accounting of reclaimed lands.

With the help of the proposed quality methodology of providing state and municipal services in the electronic form we assessed the most popular service on the portal "Providing information received during accounting of reclaimed lands".

For this public service, an applicant personally submits a letter of application in hard copy or in the form of an electronic document by mail or using public communication networks, including through the official website of the federal state information system Unified Portal of State and Municipal Services (Functions), through the official website of the Ministry, by sending an e-mail to the address of the Ministry of Agriculture of Russia or the Department of Reclamation.

\section{Results and discussion}

The authors conducted the quality analysis of this electronic public service on the basis of the proposed

\begin{tabular}{|c|c|c|c|}
\hline No. & Indicator & $\begin{array}{l}\text { Specific weight, } \\
\text { points }\end{array}$ & Assessment method \\
\hline 1 & $\begin{array}{l}\text { Approved administrative regulations for } \\
\text { electronic public services provided by a } \\
\text { public authority }\end{array}$ & 3 & $\begin{array}{c}\text { There are approved administrative regulations of } \\
\text { electronic public service }\end{array}$ \\
\hline 2 & $\begin{array}{l}\text { Monitoring of electronic public services to } \\
\text { an applicant's request }\end{array}$ & 3 & $\begin{array}{l}\text { There is a possibility of monitoring via website, } \\
\text { SMS, e-mail, single phone number and/or hotline/call } \\
\text { center }\end{array}$ \\
\hline 3 & $\begin{array}{c}\text { Online surveys to improve electronic } \\
\text { public services }\end{array}$ & 0 & $\begin{array}{l}\text { There are no online surveys to improve electronic } \\
\text { public services }\end{array}$ \\
\hline 4 & $\begin{array}{l}\text { Assessment tool of electronic public } \\
\text { services }\end{array}$ & 3 & There is a functioning assessment tool \\
\hline 5 & $\begin{array}{l}\text { Degree of automation of electronic public } \\
\text { services }\end{array}$ & 1 & Only through the Single Portal \\
\hline 6 & $\begin{array}{l}\text { Degree of maturity of electronic public } \\
\text { services }\end{array}$ & 1 & $\begin{array}{l}\text { Interactive public services in the form of bilateral } \\
\text { information exchange }\end{array}$ \\
\hline 7 & $\begin{array}{l}\text { Compliance with deadlines for electronic } \\
\text { public services }\end{array}$ & 3 & There is no violation of deadlines \\
\hline \multirow[t]{2}{*}{8} & Satisfaction with electronic public services & 1 & Satisfactory \\
\hline & Total score & & 15 \\
\hline
\end{tabular}
methodology (Table 3).

Table 3. Method of quality assessment of a public service "Providing information received during accounting of reclaimed lands" 
The efficiency polygon of state and municipal services is a proposed method, which allows quickly analyzing the quality of service in accordance with the methodology and developing effective measures to increase the level of competitiveness of products. [9]
The principle of this method is to assess key indicators and then visualize the results in the form of a polygon.

Each face of a polygon represents a separate indicator of an assessed service.

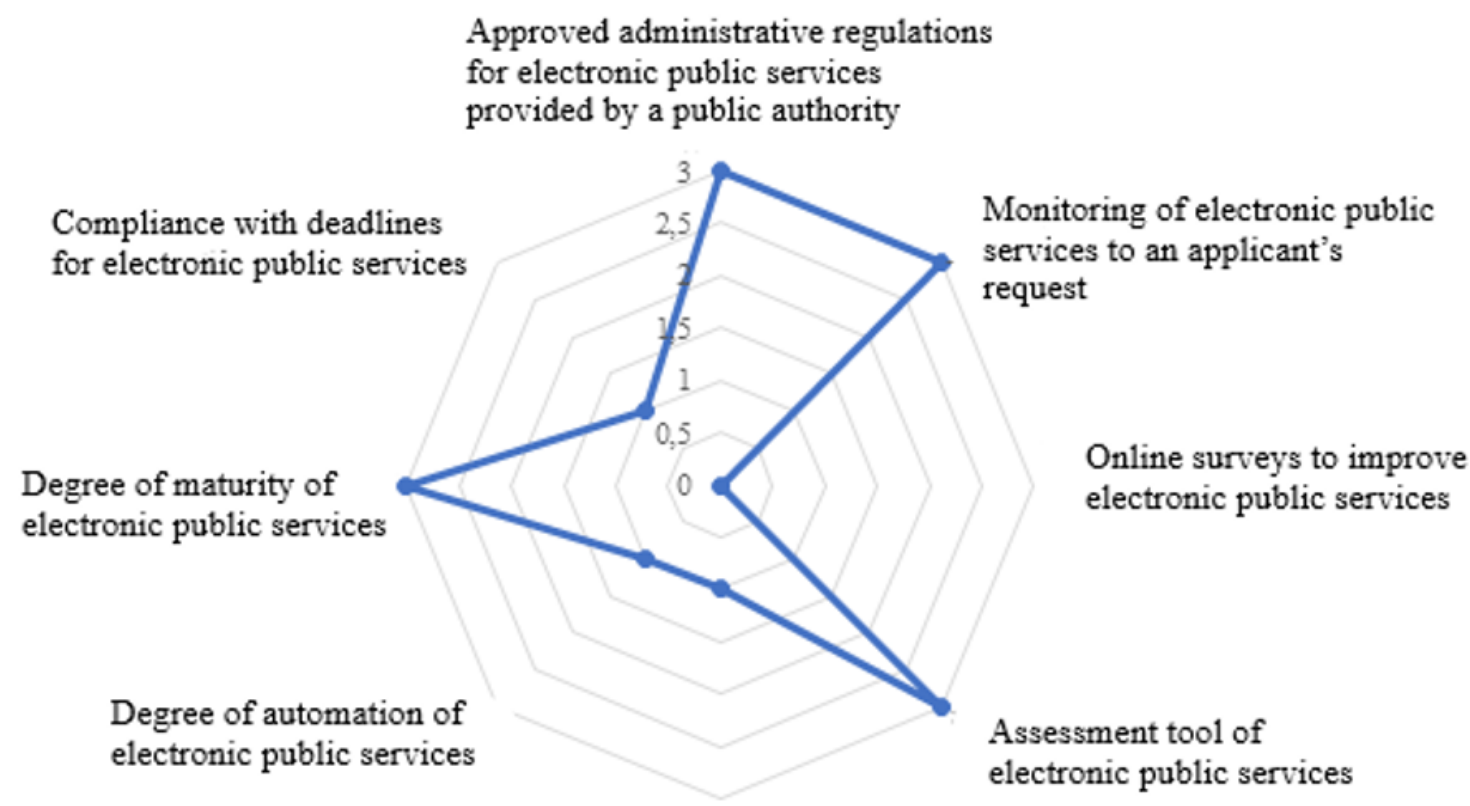

Fig. 1. Efficiency polygon of the service "Providing information received during accounting of reclaimed lands"

The figure shows that the weakest indicator of the analyzed service is the lack of online surveys on the improvement of an electronic public service, so the recommendation for the Ministry of Agriculture of the Russian Federation is to develop mechanisms to receive feedback from recipients of a service on the Portal of Public Services of the Russian Federation.

\section{Conclusion}

Timely assessment of efficiency and quality of public services in the electronic form helps to make good management decisions for all actors of the system of provision and delivery of public electronic services and to improve their quality. [10]

Thus, it is possible to conclude that the assessment of the efficiency of public services includes budgetary, economic and social efficiency, which is determined by the methods of system analysis. The efficiency assessment of public services is an important part of a management cycle, which shall be considered as a tool for efficient spending of public funds for quality delivery of public services.

\section{References}

1. T. V. Kalashnikova, S. V. Sorokin et al., Smart Technologies in the Process of Adaptation of Newly Recruited Employees at Industrial Enterprises, in Innovation Management, Development
Sustainability, and Competitive Economic Growth: proc. of the 28th Int. Business Information Management Association Conf. (IBIMA), 1236-1239 (Seville, Spain, 9-10 November 2016)

2. Ch. R. Safiullina, N.A. Safiullin, Portal of state and municipal services of the Republic of Tatarstan as an element of e-government, In Problems of economic growth and sustainable development of territories: Mat. of the III int. sci. and pract. Internet conf. in 2 parts, 315-317 (2019)

3. N.A. Safiullin, Ch.R. Safiullina, Performance evaluation of the portal of state and municipal services of the Republic of Tatarstan based on SWOT analysis, in Scientific and technological progress in agricultural production. Coll. of reports of the XIII Int. sci. and pract. conf. of young scientists, 174-178 (2018)

4. F. Sáab, Á. Rochac, M. Pérez Cotaa, Potential dimensions for a local e-Government services quality model, retrieved from: https://doi.org/10.1016/j.tele.2015.08.005.

5. A.N. Terehova, Quality Assessment of State (Municipal) Services, Innovation Economy: Prospects for Development and Improvement, 8(34) (2018)

6. M. Soledad Janita, F. Javier Miranda, Quality in eGovernment services: A proposal of dimensions from the perspective of public sector employees, Telematics and Informatics, 35(2), 457-469 (2018) 
Retrieved

from: https://doi.org/10.1016/j.tele.2018.01.004.

7. Sakari Taipale, The use of e-government services and the Internet: The role of socio-demographic, economic and geographical predictors, Telecommunications Policy, 37(4-5), 413-422 (2013) Retrieved from: https://doi.org/10.1016/j.telpol.2012.05.005.

8. J. D. Twizeyimana, A. Andersson, The public value of e-Government - A literature review, Government Information Quarterly, 36(2), 167-178 (2019)
Retrieved from: https://doi.org/10.1016/j.giq.2019.01.001.

9. K. Gasova, K. Stofkova, e-Government as a Quality Improvement Tool for Citizens' Services, Procedia Engineering, 192, 225-230 (2017) Retrieved from: https://doi.org/10.1016/j.proeng.2017.06.039.

10. F. Iannacci, A. P. Seepma, C. de Blok, A. Resca, Reappraising maturity models in e-Government research: The trajectory-turning point theory, The J. of Strategic Information Systems, 28(3), 310-329 (2019) Retrieved from: https://doi.org/10.1016/j.jsis.2019.02.001. 